\title{
SIFAT FISIK, SIFAT ORGANOLEPTIK, KADAR SERAT PANGAN KUE CUBIT DENGAN PENCAMPURAN OKRA DAN GARUT
}

\section{[Physical Properties, Organoleptic Properties and Dietary Fiber Contents of Pinch Cake with the Mixing of Okra and Garut]}

\author{
Noviati Dwi Pratiwi ${ }^{1}$, Agus Wijanarka ${ }^{2}$, Fery Lusviana Widiany ${ }^{1 *}$ \\ ${ }^{1}$ Program Studi Gizi Program Sarjana, Fakultas Ilmu Kesehatan, Universitas Respati Yogyakarta, \\ Yogyakarta, Indonesia \\ 2 Jurusan Gizi, Politeknik Kesehatan Yogyakarta, Yogyakarta, Indonesia \\ *email : lusviana86@gmail.com
}

Diterima 13 Maret 2021 / Disetujui 20 April 2021

\begin{abstract}
This study aims to determine the effect of mixing okra flour and arrowroot flour in making pinch cake on physical properties, organoleptic properties and dietary fiber content. This was a pure experimental study with a simple randomized design. The independent variable was variation in mixing okra flour and arrowroot flour, while the dependent variables were physical properties, organoleptic properties and dietary fiber content. There were four variations of pinch cake studied, with the ratio of wheat flour: okra flour: arrowroot flour by $100 \%: 0 \%: 0 \%$, 70\%: 15\%: 15\%, 50\%: 25\%: 25\%, and 30\%: 35\%:35\%. Data were analyzed univariate and bivariate. The results showed that the physical properties of the cubit cake had a slightly soft texture and a brownish yellow color. Pinch cake with the most preferred treatment is B variation, with the proportion of wheat flour: okra flour: arrowroot flour mixing is $70 \%: 15 \%: 15 \%$. The highest dietary fiber content is found in kue cubit $\mathrm{B}$, which is $17.8 \%$. Variation of mixing okra flour and arrowroot flour have a significant effect on the physical properties, organoleptic properties and dietary fiber content of pinch cake.
\end{abstract}

Keywords: Pinch Cake, Okra (Abelmoschus esculentus), Arrowroot (Maranta arundinacea L.), Physical Properties

\section{ABSTRAK}

Penelitian ini bertujuan untuk mengetahui pengaruh pencampuran tepung okra dan tepung garut pada pembuatan kue cubit terhadap sifat fisik, sifat organoleptik dan kadar serat pangan. Penelitian berjenis eksperimental murni dengan rancangan acak sederhana. Variabel bebasnya variasi pencampuran tepung okra dan tepung garut, sedangkan variabel terikatnya uji sifat fisik, uji organoleptik dan kadar serat pangan. Terdapat empat variasi kue cubit yang diteliti yaitu dengan perbandingan tepung terigu: tepung okra: tepung garut sebesar 100\%:0\%:0\%, 70\%:15\%:15\%, 50\%:25\%:25\%, dan 30\%:35\%:35\%. Data dianalisis univariat dan bivariat. Hasil penelitian menunjukkan bahwa sifat fisik secara objektif kue cubit memiliki tekstur agak empuk dan warna kuning kecoklatan. Kue cubit dengan perlakuan yang paling disukai adalah kue cubit B, dengan proporsi pencampuran tepung terigu: tepung okra: tepung garut sebesar 70\%:15\%:15\%. Kadar serat pangan tertinggi terdapat pada kue cubit B yaitu 17,8\%. Variasi pencampuran tepung okra dan tepung garut berpengaruh signifikan terhadap sifat fisik, tingkat kesukaan dan kadar serat pangan kue cubit.

Kata Kunci : Kue Cubit, Okra (Abelmoschus esculentus), Garut (Maranta arundinacea L.), Sifat Fisik

\section{PENDAHULUAN}

Buah dan sayur merupakan sumber

utama serat, namun proporsi konsumsi

buah/sayur kurang dari 5 porsi pada penduduk

usia $\geq 5$ tahun sebesar 95,5\% pada tahun 2018

(Kementerian Kesehatan Republik Indonesia, 2018). Proporsi ini dilaporkan terjadi peningkatan dibandingkan pada tahun 2013 sebesar 93,5\% (Kementerian Kesehatan Republik Indonesia, 2013).

Salah satu pangan lokal Indonesia yang memiliki kandungan serat tinggi adalah okra. Okra merupakan tanaman introduksi di Indonesia. Sedikit peminat okra dikarenakan banyak yang tidak memahami gizi dan manfaat. Okra sangat penting untuk dibudidayakan 
karena memiliki manfaat besar dalam penyediaan nutrisi yang dibutuhkan tubuh berupa serat larut dalam bentuk lendir dan peptin (Rustiawan et al., 2009). Okra dilaporkan memiliki kandungan energi sebesar $30 \mathrm{kcal}$ dan serat sebesar 3,2 g per $100 \mathrm{~g}$ berat dapat dimakan (BDD) (Agustiana et al., 2020).

Indonesia memiliki banyak jenis bahan pangan lokal yang dapat digunakan untuk menunjang ketahanan pangan nasional. Bahan pangan lokal tidak hanya tersedia dalam jumlah besar tetapi juga memililki nilai produktivitas tinggi dan kandungan gizi yang baik. Tanaman garut (maranta arundinacea L.) telah dirancang pemerintah sebagai salah satu komoditas bahan pangan yang memperoleh prioritas untuk dikembangkan karena memiliki potensi sebagai pengganti tepung terigu (Husniarti, 2001).

Umbi garut merupakan sumber potensial tepung terigu. Umbi garut memiliki kandungan karbohidrat yang tinggi sehingga dapat digunakan sumber pangan alternatif, sebagai bahan baku pengganti pangan sumber karbohidrat seperti beras dan gandum (Anayuka, 2016).

Garut dilaporkan memiliki kandungan energi sebesar $102 \mathrm{kcal}$, protein $1,0 \mathrm{~g}$, lemak $0,2 \mathrm{~g}$, karbohidrat $24,1 \mathrm{~g}$, dan serat sebesar 1,7 $\mathrm{g}$ per $100 \mathrm{~g}$ BDD. Tepung garut dilaporkan memiliki kandungan energi sebesar $355 \mathrm{kcal}$, protein $0,7 \mathrm{~g}$, lemak $0,2 \mathrm{~g}$, karbohidrat $85,2 \mathrm{~g}$, dan serat 0,4 g sebesar per $100 \mathrm{~g}$ BDD (Kementerian Kesehatan Republik Indonesia, 2018). Disamping itu, umbi garut memiliki manfaat kesehatan karena indeks glisemiknya lebih rendah dibandingkan umbi-umbian yang lainnya, yaitu hanya sebesar 14 . Indeks glikemik gembili dilaporkan sebesar 90, kimpul sebesar 95, ganyong sebesar 105, dan ubi jalar sebesar 179 (Marsono, 2002).

$$
\text { Dalam rangka meningkatkan }
$$

ketahanan pangan nasional, salah satunya adalah diversifikasi pangan yang bertujuan agar Indonesia tidak lagi mengimpor gandum. Badan Ketahanan Pangan bagian Pusat Konsumsi Keamanan Pangan juga telah mencanangkan salah satu program peningkatan pemanfaatan pangan lokal melalui tepung-tepungan.
Okra dan umbi garut dapat ditepungkan terlebih dahulu untuk memperpanjang lama simpan. Tepung okra dan tepung garut dapat diolah menjadi bahan baku pembuatan jajanan lokal seperti kue cubit. Kue cubit merupakan salah satu jajanan lokal yang populer saat ini. Penelitian ini dilakukan untuk mengetahui pengaruh pencampuran tepung okra dan tepung garut pada pembuatan kue cubit terhadap sifat fisik, sifat organoleptik dan kadar serat pangan.

\section{BAHAN DAN METODE}

\section{Bahan}

Bahan yang digunakan dalam penelitian ini adalah umbi garut yang diperoleh dari Desa Losari kecamatan Cangkringan kabupaten Sleman, buah okra yang dibeli di Carefour, telur, gula halus, margarin, susu cair, baking powder, vanili, dan pewarna alami.

Alat yang digunakan dalam penelitian ini meliputi pisau, baskom, blender, timbangan, ayakan tepung, tampah, oven, piring, sendok, loyang, kompor, cetakan kue cubit, mixer, Chromameter CR-400, Universal Testing Machine (UTM), form uji kesukaan, piring, dan pulpen.

\section{Metode}

Metode yang digunakan dalam penelitian ini adalah metode eksperimental murni. Uji organoleptik dilakukan dengan menggunakan formulir uji kesukaan berskala 6 poin, melibatkan 30 orang panelis agak terlatih. Panelis yang terlibat dalam penelitian ini telah menandatangani informed consent. Penelitian ini memperoleh Ethical Clearance dari Komisi Etik Penelitian Kesehatan, Fakultas Ilmu Kesehatan Universitas Respati Yogyakarta dengan No.262.3/FIKES/PL/VIII/2019.

Uji sifat fisik tekstur dilakukan di Laboratorium Departemen Teknologi Pangan dan Hasil Pertanian Universitas Gadjah Mada menggunakan alat Universal Testing Machine (UTM). Kue cubit ditempatkan pada suatu wadah dan pada bagian tengah kue cubit ditusukkan penetrator dari Universal Testing Machine (UTM) untuk menguji tingkat kekerasan dari kue cubit. Tingkat kekerasan 
dilihat dari gaya maksimal yang digunakan jarum Universal Testing Machine (UTM) untuk menembus kue cubit hingga mencapai alas. Pengujian tekstur kue cubit dilakukan dengan menggunakan pnetrometer Universal Testing Machine (UTM) dengan dua kali pengulangan.

Uji sifat fisik warna dilakukan secara objektif di Laboratorium Departemen Teknologi Pangan dan Hasil Pertanian Universitas Gadjah Mada menggunakan alat Chromameter CR-400. Pengujian ini dilakukan dengan cara meletakkan kue cubit pada wadah yang sudah tersedia, lalu mengatur kalibrasi awal Chromameter dengan standar $\mathrm{Y}=93,9$; $\mathrm{X}=.3134 ; \mathrm{y}=.3193$; dan didapatkan hasil berupa nilai L*a*b* (Nugrahani, 2014).

Warna kue cubit dengan pencampuran tepung okra dan tepung garut diukur dengan menggunakan alat Chromameter $C R-400$ yang menghasilkan nilai $L^{*}, a^{*}$ dan $b^{*}$. Semakin tinggi nilai $L^{*}$ (Lightness) antara 0 sampai 100 menunjukkan warna kue cubit semakin cerah. Semakin tinggi nilai a* antara 0 sampai 60 maka semakin merah warna kue cubit dan warna hijau antara 0 sampai -60 , semakin tinggi nilai b* antara 0 sampai 60 maka semakin kuning warna kue cubit dan warna biru antara 0 sampai -60 .

Pembuatan tepung garut, tepung okra, kue cubit, dan uji organoleptik dilaksanakan di Laboratorium Dietetik dan Kuliner Universitas Respati Yogyakarta. Uji organoleptik dilakukan dengan menggunakan uji kesukaan berskala 6 poin, yaitu skor 1 untuk kategori sangat tidak suka, skor 2 untuk kategori tidak suka, skor 3 untuk kategori kurang suka, skor 4 untuk kategori agak suka, skor 5 untuk kategori suka, dan skor 6 untuk kategori sangat suka. Kadar serat pangan dianalisis di Laboratorium Chemix Pratama Yogyakarta dengan metode enzimatis.

\section{Pelaksanaan Penelitian :}

1. Proses pembuatan tepung okra
a. Sortasi
Sortasi atau pemilihan okra bertujuan untuk memilih buah okra yang tidak busuk, tidak berlubang agar menghasilkan tepung yang berkualitas.
b. Pencucian dan pemotongan

Pencucian okra dengan air mengalir hingga bersih, okra yang telah dicuci bersih selanjutnya dipotong kecil agar mempercepat dalam proses pengeringan.

c. Pengeringan

Potongan okra dihamparkan pada baki cabinet dryer, pengeringan tepung okra dilakukan menggunakan cabinet dryer dengan suhu $50^{\circ} \mathrm{C}$ selama 4 jam.

d. Penepungan

Potongan okra yang telah kering dihaluskan dengan blender sehingga menghasilkan tepung yang halus dan memudahkan dalam pengayakan.

e. Pengayakan

Pada pengayakan tepung okra menggunakan ayakan tepung 60 mesh untuk memisahkan batang-batang kecil.

f. Pengemasan

Tepung okra yang sudah jadi dikemas dalam plastik kedap udara agar tepung tidak lembab.

2. Pembuatan tepung umbi garut

a. Sortasi

Sortasi atau pemilihan umbi garut bertujuan untuk memilih umbi garut yang tidak busuk, tidak berlubang atau berongga agar menghasilkan tepung yang berkualitas.

b. Pengupasan, pencucian dan diparut Kupas umbi garut, kemudian cuci dengan air mengalir hingga bersih, umbi garut yang telah dicuci bersih selanjutnya umbi garut diparut agar mempercepat dalam proses pengeringan.

c. Pengeringan

Hasil parutan umbi garut dihamparkan pada baki cabiner dryer, pengeringan tepung umbi garut dilakukan menggunakan cabinet dryer dengan suhu $50^{\circ} \mathrm{C}$ selama 4 jam.

d. Penepungan

Potongan umbi garut yang telah kering dihaluskan dengan blender sehingga menghasilkan tepung yang halus dan memudahkan dalam pengayakan.

e. Pengayakan 
Pada pengayakan tepung imbi garut menggunakan ayakan tepung 60 mesh untuk memisahkan serat-serat kasar yang besar.

f. Pengemasan

Tepung umbi garut yang sudah jadi dikemas dalam plastik kedap udara agar tepung tidak lembab.

3. Proses Pembuatan Kue Cubit

\section{a. Pencampuran bahan}

Pada proses ini, mula-mula gula dan telur dikocok sampai adonanya mengembang, kemudian dimasukkan tepung terigu, susu, margarin, vanili, banking powder dan soda kue. Pengocokan dilakukan hingga semua bahan tercampur rata atau homogen.

b. Pemasakan

Cetakan kue cubit dipanaskan terlebih dahulu di atas api kecil yang lalu dioleskan dengan sedikit margarin. Setelah panas, tuangkan adonan kue cubit dengan volume setengah cetakan lalu ditutup agar panasnya merata. Adonan sampe ditunggu hingga mengembang serta bagian bawah kue sedikit berwarna coklat muda yang menandakan kue sudah matang.

\section{Rancangan Percobaan dan Analisis Data}

Rancangan percobaan yang digunakan adalah Rancangan Acak Sederhana (RAS) menggunakan satu faktor yaitu variasi pencampuran tepung okra dan tepung garut yang terdiri atas 3 perlakuan yaitu variasi $B$, variasi $C$, dan variasi $D$, serta 1 kontrol yaitu variasi A. Variasi $A$ dengan proporsi pencampuran tepung terigu : tepung okra : tepung garut sebesar 100\%:0\%:0\%, variasi B dengan proporsi $70 \%: 15 \%: 15 \%$, variasi $C$ dengan proporsi 50\%:25\%:25\%, dan variasi $D$ dengan proporsi 30\%:35\%:35\%. Masingmasing perlakuan tersebut diulang sebanyak 2 kali dan masing-masing ulangan terdapat 3 unit percobaan, sehingga diperoleh 24 unit percobaan.

Data sifat fisik dianalisis secara deskriptif untuk mengetahui karakteritik warna dan tekstur. Data sifat organoleptik dianalisis menggunakan uji Kruskall-Wallis karena data tidak terdistribusi normal. Apabila ada perbedaan dilanjutkan dengan uji MannWhitney. Data serat pangan dianalisis menggunakan uji ANOVA dan apabila ada perbedaan dilanjutkan dengan uji Least Significant Difference (LSD). Tingkat kesalahan yang dapat ditoleransi (a) sebesar $5 \%$.

\section{HASIL DAN PEMBAHASAN}

\section{Sifat Fisik}

\section{a. Tekstur}

Hasil uji sifat fisik tekstur kue cubit pada Tabel 1 menunjukkan bahwa kue cubit A (kontrol) memiliki tekstur yang lebih keras yaitu dengan nilai Fmax 5,9542, sedangkan kue cubit $D$ dengan proporsi pencampuran tepung okra dan tepung garut paling besar dibandingkan variasi pencampuran yang lainnya didapatkan nilai Fmax sebesar 3,5557. Semakin banyak proporsi pencampuran tepung okra dan tepung garut, tekstur kue cubit semakin lunak.

\begin{tabular}{ccc} 
Variasi & $\begin{array}{c}\text { Proporsi pencampuran } \\
\text { tepung terigu, tepung okra, } \\
\text { tepung garut }\end{array}$ & $\begin{array}{c}\text { Tekstur } \\
\text { (Fmax. N) }\end{array}$ \\
\hline A & $(100 \%: 0 \%: 0 \%)$ & 5,9542 \\
\hline B & $(70 \%: 15 \%: 15 \%)$ & 5,9133 \\
\hline C & $(50 \%: 25 \%: 25 \%)$ & 6,4969 \\
\hline D & $(30 \%: 35 \%: 35 \%)$ & 3,5557 \\
\hline
\end{tabular}

Tabel 1. Hasil uji sifat fisik tekstur kue cubit menggunakan alat pnetrometer UTM

Tekstur makanan sangat
dipengaruhi oleh bahan-bahan
penyusunnya seperti tepung terigu, telur
dan bahan lainnya. Telur berfungsi sebagai
pengembang, pengemulsi, koagulan dan
pengikat air. Tepung terigu mengandung
protein dalam bentuk gluten yang apabila
bertemu dengan air dapat bermanfaat untuk
mengikat dan membuat adonan menjadi
elastis sehingga mudah dibentuk.

Adyana (2017) menyebutkan bahwa tepung garut tidak mengandung g/uten yang berfungsi pembentuk sifat yang kenyal, yang membuat produk yang dihasilkan tepung garut lunak. Tepung okra 
pun tidak memiliki kandungan gluten (Astawan, 2006). Hal itu menyebabkan pencampuran tepung okra dan tepung garut sebagai pengganti tepung terigu justru dapat memberikan dampak positif pada kue cubit yang diproduksi. Dampak positif tersebut adalah bahwa kue cubit yang diproduksi memiliki kandungan gluten yang lebih rendah sehingga dapat dikonsumsi oleh orang-orang yang sensitif terhadap gluten. Gluten dapat merangsang timbulnya bakteri Candida yang menimbulkan gas, toksik, sembelit, kembung dan diare (Balittro, 2014).

\section{b. Warna}

Hasil penelitian pada Tabel 2 menunjukkan bahwa semakin besar proporsi pencampuran tepung okra dan tepung garut, maka semakin rendah nilai kecerahan kue cubit yaitu dengan nilai kecerahan $\left(L^{*}\right)$ antara $74,26-46,99$.

Nilai a* berkisar antara $1,36-3,21$ menunjukkan warna merah. Nilai $b^{*}$ berkisar antara 45,09-28,02 menunjukkan warna kuning. Semakin banyak proporsi pencampuran tepung okra dan tepung garut, warna kue cubit yang dihasilkan akan semakin gelap (Gambar 1).

Pencampuran tepung okra menghasilkan warna adonan menjadi hijau. Semakin banyak proporsi pencampuran tepung okra pada pembuatan kue cubit, maka warna yang dihasilkan akan semakin hijau. Warna hijau yang dihasilkan oleh tepung okra disebabkan adanya kandungan klorofil.

Okra yang sudah jadi tepung memiliki karakteristik warna yang lebih cerah dibandingkan dengan okra yang masih segar. Hasil penelitian dilaporkan oleh Fauza et al. (2019) bahwa pengeringan buah okra menjadi tepung okra tidak merusak aktivitas antioksidan. Proses pengeringan tepung okra dapat meningkatkan derajat kecerahan okra.

Tabel 2. Hasil uji sifat fisik warna kue cubit menggunakan alat Chromameter CR-400

\begin{tabular}{|c|c|c|c|c|}
\hline Variasi & $\begin{array}{c}\text { Proporsi } \\
\text { pencampuran } \\
\text { tepung terigu, } \\
\text { tepung okra, } \\
\text { tepung garut }\end{array}$ & $L^{*}$ & $a^{*}$ & $\mathrm{~b}^{*}$ \\
\hline A & $\begin{array}{c}(100 \%: 0 \%: \\
0 \%)\end{array}$ & 74,26 & 1,36 & 45,09 \\
\hline B & $\begin{array}{c}\text { (70\%: } 15 \%: \\
15 \%)\end{array}$ & 53,22 & 2,80 & 32,42 \\
\hline C & $\begin{array}{c}\text { (50\%: } 25 \%: \\
25 \%)\end{array}$ & 51,06 & 3,21 & 33,05 \\
\hline D & $\begin{array}{c}(30 \%: 35 \% \\
: 35 \%)\end{array}$ & 46,99 & 2,84 & 28,02 \\
\hline
\end{tabular}

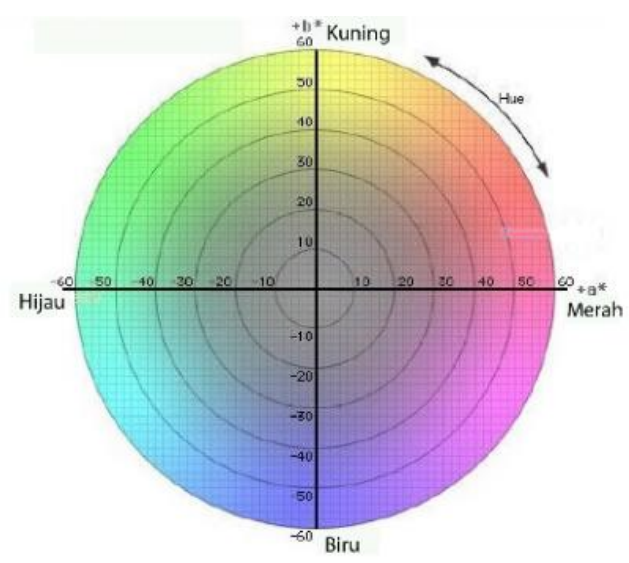

Gambar 1. Kecerahan ( $\left.L^{*}\right)$ kue cubit dengan pencampuran tepung okra dan tepung garut

Pati garut mengandung kadar karbohidrat (by difference) yang tinggi yaitu sebesar 98,74\%. Meskipun demikian, kandungan gula pereduksi pada pati garut tergolong kecil yaitu 4,96\% (Faridah et al., 2014). Gula pereduksi tersebut berpotensi menimbulkan warna kecoklatan pada proses pembuatan kue cubit dalam penelitian ini. Reaksi pencoklatan non-enzimatis terjadi karena adanya reaksi antara gula pereduksi dengan gugus amino atau protein (reaksi maillard) (Catrien et al., 2008). Reaksi maillard terjadi karena reaksi antara karbohidrat (gula pereduksi) dengan gugus amino, seperti pencoklatan pada berbagai roti (Winarno, 2002).

\section{Sifat Organoleptik}

Hasil uji organoleptik dengan uji Kruskal Wallis ditampilkan pada Tabel 3. Hasil 
Versi Online:

http://WWW.profood.unram.ac.id/index.php/profood ISSN: 2443-3446

menunjukkan bahwa terdapat perbedaan yang signifikan pada variasi pencampuran tepung garut dan tepung okra $(p$-value $<0,05)$.

Tabel 3. Hasil analisis uji Kruskal-Wallis

\begin{tabular}{|c|c|c|c|c|c|}
\hline \multirow{5}{*}{$\begin{array}{l}\text { Sifat } \\
\text { Fisik }\end{array}$} & \multicolumn{3}{|c|}{ Mean Rank } & \multirow[b]{2}{*}{ Nilai $p$} & \\
\hline & \multicolumn{3}{|c|}{$\begin{array}{l}\text { Proporsi pencampuran } \\
\text { tepung terigu : } \\
\text { tepung okra : tepung } \\
\text { garut }\end{array}$} & & \\
\hline & $(100$ & $(70 \%: 1$ & $(50 \%: 2$ & (30\%:3 & \\
\hline & $\%: 0 \%$ & $5 \%: 15$ & $5 \%: 25$ & 5\%:35 & \\
\hline & :0\%) & $\%)$ & $\%)$ & $\%)$ & \\
\hline Warna & $96.47^{a}$ & $59,47^{b}$ & $51,95^{\mathrm{b}}$ & $34,12^{c}$ & 0,000 \\
\hline Aroma & $72,07^{a}$ & $63,07^{a b}$ & $49,28^{c b}$ & $57,58^{a c}$ & 0,043 \\
\hline Rasa & $81,13^{a}$ & $56,62^{b}$ & $54,68^{b}$ & $49,57^{b}$ & 0,001 \\
\hline $\begin{array}{c}\text { Tekstu } \\
r\end{array}$ & $79,85^{a}$ & $47,67^{b}$ & $67,4^{\mathrm{a}}$ & $47,00^{b}$ & 0,000 \\
\hline
\end{tabular}

Keterangan : Notasi huruf yang berbeda (a, b, c, d) pada baris yang sama menyatakan ada perbedaan yang nyata berdasarkan mannwhitney

\section{a. Warna}

Hasil uji organoleptik berdasarkan warna ditampilkan pada Gambar 2. Kue cubit yang paling disukai berdasarkan warna adalah kue cubit variasi $B$, yaitu dengan proporsi pencampuran tepung terigu: tepung okra: tepung garut sebesar 70\%:15\%:15\%. Hasil uji statistik menggunakan uji Kruskall-Wallis menunjukkan bahwa ada perbedaan tingkat kesukaan panelis terhadap warna kue cubit dengan hasil $p=0,000(p<0.05)$.

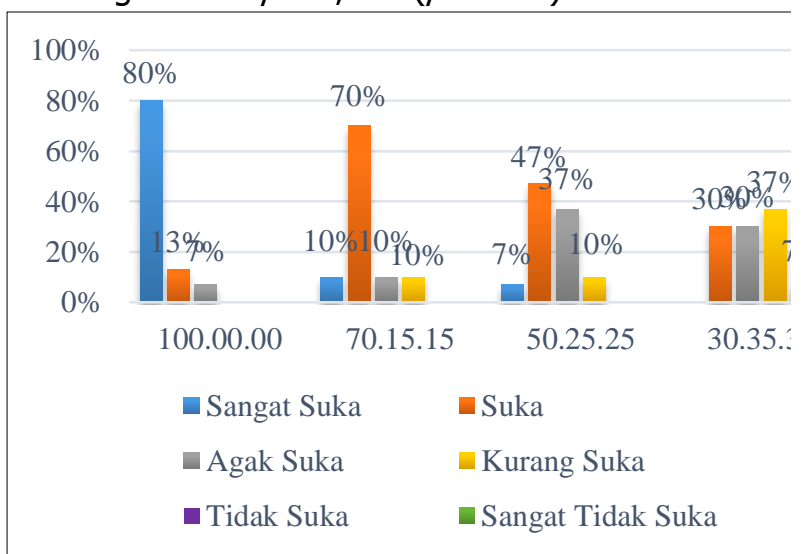

Gambar 2. Tingkat kesukaan panelis terhadap warna kue cubit
Pro Food (Jurnal Ilmu dan Teknologi Pangan) Vol 7 No. 1 Mei 2021 e-

ISSN: 2443-1095

Pencampuran tepung okra dan tepung garut pada pembuatan kue cubit berpengaruh terhadap hasil uji organoleptik berdasarkan warna. Perubahan warna pada produk kue cubit terjadi berkaitan dengan reaksi mailard. Semakin besar proporsi pencampuran tepung okra, akan menghasilkan perubahan warna dari hijau kecoklatan sampai hijau gelap, karena adanya reaksi antara gula pereduksi dengan gugus amin yang terbebas dari asam amino atau protein (Simpson, 2012).

Hasil penelitian ini sejalan dengan hasil yang telah dilaporkan oleh Agustiana et al. (2020) bahwa semakin besar proporsi pencampuran tepung okra maka semakin hijau tua atau pekat warna yang dihasilkan produk tersebut. Warna hijau ini dihasilkan dari pigmen klorofil yang terkandung dalam okra, jika okra segar berwarna hijau tua, namun jika sudah diproses menjadi tepung, maka okra menjadi berwarna hijau muda atau kehijauan, sehingga dapat mempengaruhi warna dari produk yang dihasilkan.

\section{b. Aroma}

Hasil pada Gambar 3 menunjukkan bahwa kue cubit dengan perlakuan yang disukai oleh sebagian besar panelis adalah kue cubit variasi B. Hasil uji statistik menggunakan uji Kruskall-Wallis menunjukkan bahwa ada perbedaan tingkat kesukaan panelis terhadap aroma kue cubit dengan hasil $p=0,000(p<0.05)$.

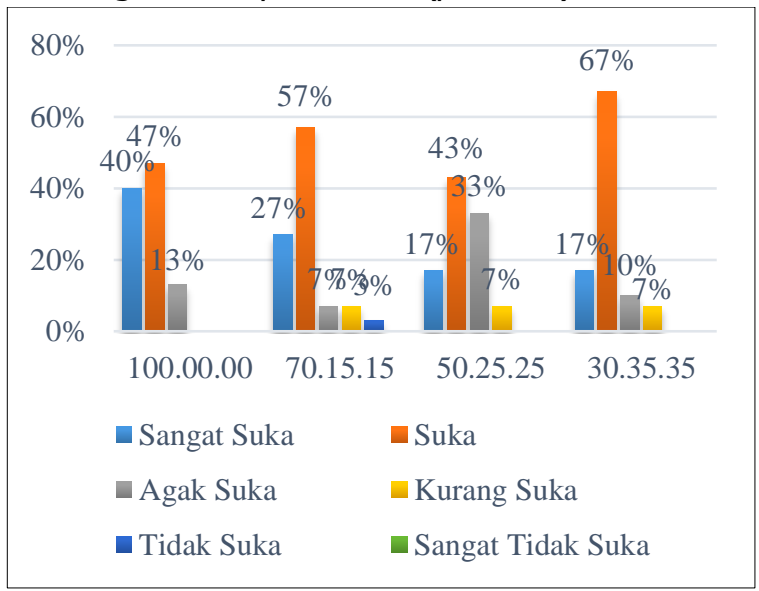

Gambar 3. Tingkat kesukaan panelis terhadap aroma kue cubit 
Aroma kue cubit yang dihasilkan dari tepung okra dan tepung garut yang digunakan, yaitu yang paling kuat tercium aroma khas okra. Semakin besar proporsi pencampuran tepung okra, maka akan semakin menambah aroma khas okra. Aroma yang paling kuat terdapat kue cubit D. Penerimaan konsumen terhadap makanan ditentukan juga oleh aroma makanan. Aroma juga dipengaruhi oleh komposisi bahan yang digunakan dalam suatu produk makanan.

Agustiana et al. (2020) menyebutkan bahwa dalam pembuatan mie menggunakan tepung okra, aroma yang disukai pada proporsi pencampuran $10 \%$ atau $10 \mathrm{~g}$ tepung okra. Dalam penelitian tersebut pencampuran $10 \%$ merupakan proporsi pencampuran tepung okra yang paling sedikit. Semakin kecil proporsi pencampuran tepung okra, maka tingkat kesukaan panelis menjadi semakin besar.

\section{c. Rasa}

Hasil uji organoleptik berdasarkan rasa kue cubit ditampilkan pada Gambar 4. Kue cubit yang paling disukai diantara kelompok intervensi berdasarkan rasa adalah kue cubit variasi $B$, yaitu dengan proporsi pencampuran tepung terigu: tepung okra: tepung garut sebesar 70\%:15\%:15\%. Hasil uji statistik menggunakan uji Kruskall-Wallis menunjukkan bahwa ada perbedaan tingkat kesukaan panelis terhadap rasa kue cubit dengan hasil $p=0,000(p<0.05)$.

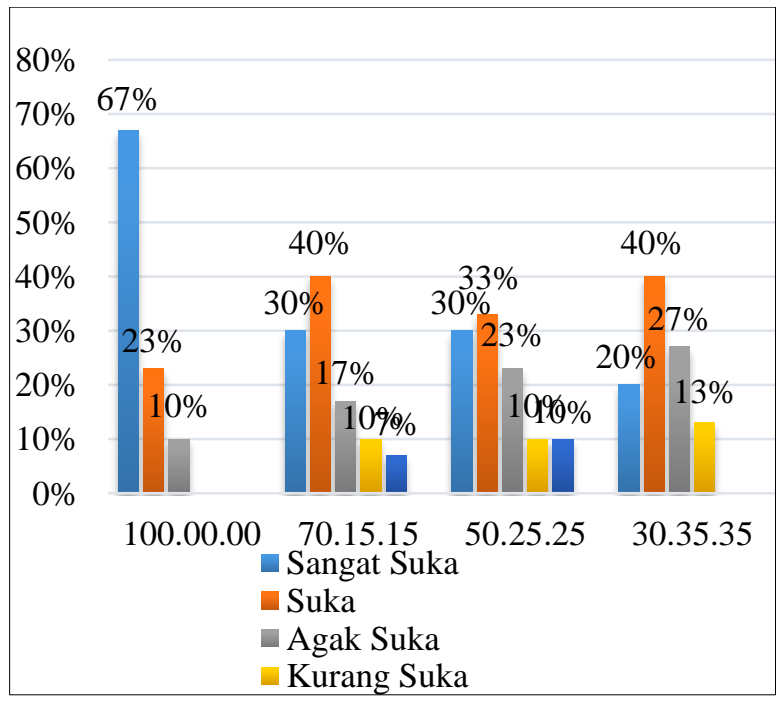

Gambar 4. Tingkat kesukaan panelis terhadap rasa kue cubit

Hasil penelitian ini menunjukkan bahwa terdapat after taste sedikit pahit terdapat pada kue cubit dengan pencampuran tepung okra. Semakin besar proporsi pencampuran tepung okra, maka semakin terasa after taste pahit pada kue cubit. Hal ini dikarenakan pada okra terdapat senyawa diosgenin yang termasuk golongan saponin. Saponin mempunyai sifat pahit (Prameswari et al., 2013).

Pada penelitian ini, panelis lebih menyukai kue cubit tanpa pencampuran tepung okra dibandingkan yang diberikan perlakuan dengan pencampuran tepung okra. Hasil ini sejalan dengan hasil penelitian yang dilaporkan oleh Agustiana et al. (2020) bahwa presentase tingkat kesukaan panelis tertinggi pada mie tanpa pencampuran tepung okra hijau. Demikian pula dengan pencampuran tepung garut, semakin kecil proporsi pencampuran tepung garut, maka semakin tinggi persentase tingkat kesukaaan panelis (Ilmannafian et al., 2018).

\section{d. Tekstur}

Hasil uji organoleptik berdasarkan tekstur kue cubit ditampilkan pada Gambar 5. Kue cubit yang paling disukai diantara kelompok intervensi berdasarkan tekstur adalah kue cubit variasi $B$, yaitu dengan proporsi pencampuran tepung terigu: 
tepung okra: tepung garut sebesar 70\%:15\%:15\%. Hasil uji statistik menggunakan uji Kruskall-Wallis menunjukkan bahwa ada perbedaan tingkat kesukaan panelis terhadap tekstur kue cubit dengan hasil $p=0,000(p<0.05)$.

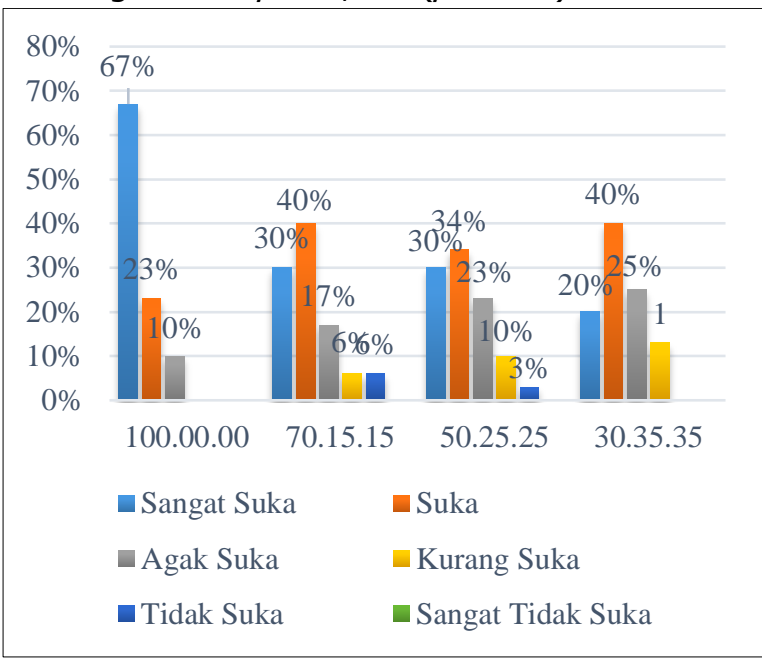

Gambar 5. Tingkat kesukaan panelis terhadap tekstur kue cubit

Semakin sedikit proporsi tepung terigu yang dicampurkan, maka kekenyalan produk akan berkurang. Tepung terigu memilki kandungan protein yaitu gliadin dan glutenin yang apabila keduanya bercampur dengan air maka akan membentuk g/uten Gluten bersifat elastis sehingga mempengaruhi kekenyalan suatu produk (Suprapti, 2005).

Tepung okra hijau memiliki struktur yang lebih kasar jika dibandingkan dengan tepung terigu yang halus dan berserbuk, karena okra tidak memiliki gluten sehingga dapat mengurangi kekenyalan pada kue cubit (Astawan, 2006).

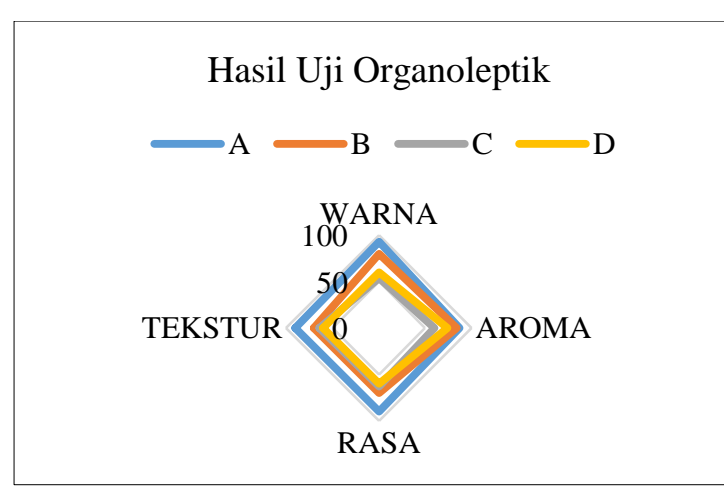

Gambar 6. Spider web hasil uji organoleptik

Hasil analisis menggunakan spider web menunjukkan bahwa kue cubit B memiliki luas kurva yang paling besar berdasarkan warna, aroma, rasa, tekstur. Hal itu menunjukkan bahwa kue cubit $B$ dengan proporsi pencampuran tepung terigu: tepung okra: tepung garut sebesar 70\%:15\%:15\% merupakan kue cubit yang paling disukai oleh panelis berdasarkan hasil uji organoleptik.

\section{Kadar Serat Pangan}

Hasil analisis kadar serat pangan pada kue cubit ditampilkan pada Tabel 4. Kadar serat pangan yang paling tinggi terdapat pada kue cubit $D$, yaitu dengan proporsi pencampuran tepung terigu : tepung okra : tepung garut sebesar 30\%:35\%:35\%. Kandungan serat pangan pada kue cubit $D$ dilaporkan sebesar $17,8 \%$.

Hasil uji statistik one-way ANOVA menunjukkan bahwa terdapat perbedaan kadar serat pangan yang signifikan pada kue cubit dengan empat variasi pencampuran tepung okra dan tepung garut $(p=0,000)$. Semakin besar proporsi pencampuran tepung okra dan tepung garut, maka semakin tinggi juga kadar serat pangan yang dihasilkan. Hal ini karena buah okra dan umbi garut memiliki kandungan serat yang tinggi. Hasil penelitian ini sejalan dengan hasil penelitian yang dilaporkan oleh Nurlin (2017) bahwa semakin banyak penambahan okra hijau dalam minuman jeli, maka semakin tinggi kadar serat pangan dalam minuman tersebut.

Tabel 4. Hasil analisis pengaruh pencampuran tepung okra dan tepung garut pada pembuatan kue cubit terhadap kadar serat pangan

\begin{tabular}{ccc}
\hline Variasi & $\begin{array}{c}\text { Proporsi pencampuran } \\
\text { tepung terigu, tepung } \\
\text { okra, tepung garut }\end{array}$ & $\begin{array}{c}\text { Kadar } \\
\text { Serat } \\
\text { Pangan } \\
(\%)\end{array}$ \\
\hline $\mathrm{A}$ & $(100 \%: 0 \%: 0 \%)$ & $9,9916^{\mathrm{a}}$
\end{tabular}


B (70\%: 15\%: 15\%) 15,38825

C (50\%: 25\%: 25\%) 16,51744b

D $\quad(30 \%: 35 \%: 35 \%) \quad 17,78122^{c}$

Keterangan : Angka yang diikuti notasi yang sama tidak berbeda nyata pada a $5 \%$

Kandungan serat pada buah okra berdasarkan USDA (2015) sebesar 3,2 gram per 100 gram okra mentah. Kandungan serat umbi garut sebesar 9,78 gram per 100 gram berat dapat dimakan. Menurut BPOM (2016), suatu bahan pangan dapat disebut sebagai sumber serat apabila memiliki kandungan serat minimal $3 \mathrm{~g} / 100 \mathrm{~g}$ bahan, sehingga okra hijau dan umbi garut dapat dikategorikan sebagai pangan sumber serat.

Serat makanan dapat diklasifikasikan menjadi dua berdasarkan kelarutan, yaitu komponen yang dapat larut meliputi pektin, gom, $\beta$-glukan dan komponen yang tidak larut meliputi selulosa, lignin, dan hemiselulosa (Dhingra et al., 2012). Serat pangan memberikan dampak positif bagi fungsi organ tubuh, diantaranya berperan sebagai laksatifa, penurun kadar kolesterol darah, dan penurun glukosa darah (Yang et al., 2017). Serat pangan berperan dalam pencegahan konstipasi, karena dapat meningkatkan berat feses dan memperpendek waktu tinggal residu makanan dalam usus. Peningkatan berat feses berkaitan dengan peningkatan jumlah sel bakteri yang berperan dalam melakukan fermentasi pada serat pangan tersebut, sehingga memberikan dampak menguntungkan terhadap pencernaan manusia. Sifat fermentasi ini menjadikan serat pangan banyak dimanfaatkan dalam penyediaan makanan prebiotik (Marsono, 2004).

\section{KESIMPULAN}

Variasi pencampuran tepung okra dan tepung garut berpengaruh signifikan terhadap sifat fisik, tingkat kesukaan dan kadar serat pangan kue cubit. Semakin besar proporsi pencampuran tepung okra dan tepung garut, maka warna yang dihasilkan akan semakin kuning kecoklatan dan tekstur akan semakin lunak. Semakin banyak tepung okra dan tepung garut yang dicampurkan dalam pembuatan kue cubit maka warna, aroma, rasa dan tekstur semakin tidak disukai panelis. Kue cubit dengan perlakuan paling disukai yaitu kue cubit B. Semakin besar proporsi pencampuran tepung okra dan tepung garut, maka kadar serat pangan dalam kue cubit menjadi semakin tinggi.

Perlu dilakukan penelitian lebih lanjut terkait pemanfaatan pangan lokal Indonesia dalam upaya pemenuhan kebutuhan gizi harian masyarakat.

\section{DAFTAR PUSTAKA}

Adyana, K. S., 2017. Indeks Glikemik dan Kadar Serat pada Mi Garut Sebagai Alternatif Makanan Pokok. Skripsi. Jurusan Gizi Politeknik Kesehatan Kementrian Kesehatan Yogyakarta, Yogyakarta.

Agustiana, A., Waluyo, W. dan Widiany, F.L., 2020. Sifat Organoleptik dan Kadar Serat Pangan Mie Basah dengan Penambahan Tepung Okra Hijau (Abelmoschus esculentum L.). Jurnal Gizi, 9 (1): 131141.

Anayuka, S. T. A., 2016. Evaluasi Sifat Fisik dan Sensori Flakes Pati Garut dan Kacang Merah dengan Penambahan Tiwul Singkong. Skripsi. Diakses dari http://thp.fp.unila.ac.id pada tanggal 1 Desember 2020.

Astawan, M., 2006. Membuat Mie dan Bihun. Penebar Swadaya. Jakarta.

Balittro, A., 2014. Umbi Garut sebagai Alternatif Pengganti Terigu untuk Individual Autistik. Warta Penelitian dan Pengembangan Tanaman Industri, 20 (2): 1-32.

BPOM Republik Indonesia., 2016. Keputusan Kepala Badan Pengawas Obat dan Makanan RI Nomor: HK.03.1.23.11.11.09909 tentang Pengawasan Klaim pada Label dan Iklan Pangan Olahan. BPOM RI. Jakarta.

Catrien, Surya, Y. S. dan Ertanto, T., 2008. Reaksi Mailard pada Produk Pangan. Diakses dari https://repository.ipb.ac.id/handle/1234 
56789/32771 pada tanggal 1 Desember 2020.

Dhingra, D., Michael, M., Rajput, H. dan Patil, R. T., 2012. Dietary Fiber in Foods: A Review. Journal of Food Science and Technology, 49 (3): 255-266.

Faridah, D. N., Fardiaz, D., Andarwulan, N., Sunarti, T. C., 2014. Karakteristik Sifat Fisikokimia Pati Garut (Maranta arundinaceae). AGRITECH, 34 (1): 1421.

Fauza, A., Djamiatun, K. dan Al-Baarri, A. N., 2019. Studi Karakteristik dan Uji Aktivitas Antioksidan dari Tepung Buah Okra (Abelmoschus esculentus). Jurnal Aplikasi Teknologi Pangan, 8 (4): 137142.

Husniarti, I. S., Utami dan Rahayu, S., 2001. Subtitusi Terigu dengan Pati Garut (Marantha arundinaceae L.) pada Pembuatan Roti Tawar. AGRITECH, 21 (1): 16-20.

Ilmannafian, A. G., Lestari, E. dan Halimah, H., 2018. Pemanfaatan Tepung Garut Sebagai Substitusi Tepung Terigu Dalam Pembuatan Kue Bingka. Jurnal Teknologi Agro-Industri, 5 (2): 141-151.

Kementerian Kesehatan Republik Indonesia., 2013. Riset Kesehatan Dasar 2013. Kementerian Kesehatan Republik Indonesia. Jakarta.

Kementerian Kesehatan Republik Indonesia., 2018. Hasil Utama Riskesdas 2018. Kementerian Kesehatan Republik Indonesia. Jakarta.

Kementerian Kesehatan Republik Indonesia., 2018. Tabel Komposisi Pangan Indonesia 2017. Kementerian Kesehatan Republik Indonesia. Jakarta.

Marsono, Y., 2004. Serat Pangan dalam Perspektif IImu Gizi. Universitas Gadjah Mada. Yogyakarta.

Nugrahani, F., 2014. Metode Penelitian Kualitatif dalam Penelitian Pendidikan Bahasa. Cakra Books. Solo.

Nurlin, L. A. dan E. Damayanthi, 2017. Kandungan Serat Pangan pada Minuman Jeli Okra Hijau (Abelmoschus esculentus
L) dan Stroberi (Fragaria ananassa). Diakses dari https://repository.ipb.ac.id/handle/1234 56789/90257 pada tanggal 1 Desember 2020.

Prameswari, R. P. dan E. Teti, 2013. Pemanfaatan Tepung Gembili (Dioscorea esculentus L.) dalam Pembuatan Cookies. Jurnal Pangan dan Agroindustri, 1 (1): 115-128.

Rustiawan, E., Jannah, H. dan Mirawati, B., 2009. Pengaruh Media Tanam terhadap Pertumbuhan Benih Okra (Abelmoschus esculentus L.) Lokal Sumbawa sebagai Dasar Penyusunan Buku Petunjuk Praktikum Fisiologi Tumbuhan. Jurnal Ilmiah Pendidikan Biologi 'Bioscientist', 5 (2): 27-33.

Simpson, B. K., 2012. Food Biochemistry and Food Processing. 2nd (ed). Diakses dari https://onlinelibrary.wiley.com/doi/book /10.1002/9781118308035 pada tanggal 1 Desember 2020

Suprapti, L., 2005. Tepung Tapioka, Pembuatan dan Pemanfaatannya. Penerbit Kanisius. Yogyakarta.

USDA., 2015. National Nutrient Database for Standard Reference. The National Agricultural Library. USA.

Winarno., 2002. Kimia Pangan dan Gizi. PT. Gramedia Pustaka Utama. Jakarta.

Yang, Y. Y., Ma, S., Wang, X. X. dan Zheng, X.L., 2017. Modification and Application of Dietary Fiber in Foods. Journal of Chemistry, 2017: 1-8. 